\title{
Teaching Religious Education for Children Based on Infallibles Sire (PBUH)
}

\author{
Mah Monir Sharifani \\ M.A. in History and Philosophy of Education, Isfahan (Khorasgan) Branch, \\ Faculty of Educational Sciences, Islamic Azad University, Isfahan, Iran. \\ Email: sharifani2014@gmail.com \\ Sayyed Hossain Vaezi \\ Assistant Professor, Department of Theology, Isfahan (Khorasgan) Branch, \\ Islamic Azad University, Isfahan, Iran, \\ Corresponding Author Email: sh.vaezi@khuisf.ac.ir
}

Doi:10.5901/mjss.2016.v7n3s3p350

\section{Abstract}

This research is based on qualitative research plan and by using content analysis method, tries to explain the relationship between religious educations within the tradition infallibles education. With the aim of religious education seeks to review and to clarify the principles of the main pillars of Islam's religious education and to achieve objectives, principles and methods of religious education. Some results suggest that, Islamic philosophy and religious education should be based on the development of human nature and away from coercion and violence. The potential should be actualized. New understanding of Islamic texts and sources should be appropriate to the circumstances, needs and innovation. Among the educational objectives associated with religion, the Qur'an and the tradition of Imams (as) is in the context of the student's life; to strengthen religious issues and use appropriate methods to fulfill make their religious understanding.

Keywords: Islam, religious education, objectives, principles, methods of religious education.

\section{Introduction}

Religion and religiosity, has a background as long as human life. So that we can say that religion and human beings have emerged at the same time. Among the phenomena and manifestations of cultural, religion always has permanent and basic role in the intellectual life of society. But to fit the changing conditions of society and obstacles, the commitment to religion have been brutally weakened (Motahari, 1988, page 47). As the human body gets sick, human religiosity as a spiritual phenomenon may also be affected. Given the relative youth of our community and because of the danger that religious youth are for the future of society; understanding the factors that underlie religious education of children and also familiarity with some problematic factors of religion to youth and trying to fix them with some points about the moral and educational recommendations is very important. According to the Quran Muslims believe that the only way to salvation is faith in God and his commands.

\subsection{Problem statement:}

The importance and necessity of education is no secret to anyone. No school can deny the importance and necessity of religious education; all disagreements are in goals and methods of human training; because one of human aspects is his upbringing and sending books and prophets are for his education and guidance. All schools, religions and countries have attached great importance of training people and childhood training. Islam particularly emphasized the religious education in early childhood education and considers it the responsibility of parents and the rights of children. Imam Ali said: "There is no better gift from a father to his child than a good education". ${ }^{1}$ (Noori Al Tabarsi, 1987 AH, vol 15, p 165). Imam Sadiq (as) about the right of the children: a child has three rights and father should fulfill it: "Choosing a good mother for him, giving him a good name and seriousness in his upbringing". All three rights would be effective in parenting but the third one is very important. (Majkesi, $1982 \mathrm{AH}, \mathrm{vol}$ 7, p 236). The sample narratives on parenting emphasized in adolescence

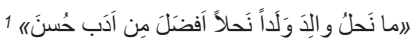


and youth. Imam Ali says: "Because the baby's heart is as empty land on which we can plant the seeds to grow; i started training you before your heart and your mind is busy until you actually experience what you experienced makes you needless to accept it again2". (Abde, Bita, vol 3, page 40) (Dashti, 2005, Letter 31, page 368). According to Imam Ali (as): First and foremost important reason of religious education in childhood is the heart of the children should be "Merciful throne"; and it is empty and it is not darkened with darkness and sin and also a child is not interrupted by earthly stuff like women, wife, children. According to Imam (as) Part of the education of man, even religious education, for a better life is in this world; for example, appropriate behavior in relation to their individual and social life, nature and other human beings and even in relation to God are things that one must know in their life. More and deeper human need in childhood and adolescence is influenced by other people and tries to copy others; another point is that in childhood and adolescence, children are available for parents and they don't have independence and free will, so there are more options for parents to educate them. (Nouri Altabrasi, 1987, vol. 15, hadith6, p 195).

Thus, according to the traditions and the points raised, parenting in childhood and adolescence is very important and it is on parents to educate their children perfectly.

\subsection{The definition of religious education:}

Religious education is a process that provides one particular way of life. This way of life is based on predetermined principles, rules, and strategies that are offered through religion and beliefs. Sometimes religious education means most notable. In this term among all aspects of education particular attention is to the spiritual growth and faith and thus all other aspects of educational and moral dimension are out of discussion. (Delshad tehrani, 1997, p 63).

\subsection{Objectives of religious education in Islam:}

In Islam, the purpose is getting people to worship and education and make them favoring servant. In fact, the goal of religious education is the present of Qur'an and the tradition of infallibles in the student's life, so we can create religion and religious perception among students with appropriate procedures and specific teachings and religious issues; Prophet Muhammad (PBUH) at the beginning of the mission with the slogan, and man-made Call of liberation and freedom anthem "Say God is One to reach salvation 3." The ultimate goal of training people from the perspective of Islam declares that a person can reach salvation. (Razi, $1999 \mathrm{AH}$, vol 32, p 349).

\subsection{Principles of religious education:}

In principles of education the basics of intellectual and scientific spirit characteristics should be examined, up to teachers become familiar with the basics of intellectual while studying at institutions of teacher training and gradually solve the problems of education of the principles with these principles. These principles express scientific attitude in best way and not only are a good guide in solving scientific problems but also prepare teachers in dealing with the everyday issues of education. (Shariatmadari, 2008, p. 31).

\section{Preparation for parenting}

\subsection{Child in Quran and traditions:}

From the perspective of verses and traditions, children are divine blessings for parents. Can take advantage of divine blessings and guidance by proper using it on the path of evolution and it also can destroy people if it's not used properly; because according to Quran, children as well as property and other gifts are device for human testing: "And to know that the property and your children are your experiments and there is a great reward that with Allah." (Al-Anfal / 28). If a person came out of the exam successfully, will have a great reward both worldly and otherworldly, because with the right education we can make children our help in future, help for mother and father, with the correct religious education of children, one can enjoy the reward that god gives to his creations, and in this case a child will be flower in paradise, a

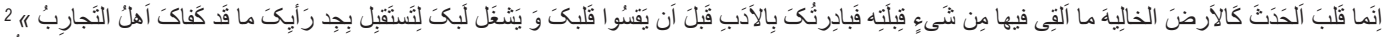

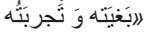

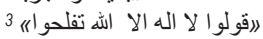


valuable thing for god. The Prophet (s) said: "Surely the righteous son is one of paradise flowers4". He also said "daughters are collection competent for their parents5." (Nouri altabasi, 1987 AH, vol 15, p 115). For whatever good that children do, it will be written is parent's account.

Imam Sadiq (AS) said: "Heritage is a child from His believing servant, who after him will worship god6". (Kalini, $1992 \mathrm{AH}$, vol. 6, p. 3). And a good child if he lives, makes prayer and good deeds for parents and if he dies before parents will plead for them in the judgment day. (Nouri altabasi, $1987 \mathrm{AH}$, vol 15, p 112).

\subsection{Preparation for religious education:}

Based on Infallibles Sire religious education for children begins before birth. It means before marriage and mate selection. By choosing mate the training center is determined, Because of factors in education, regardless of the nature, are hereditary factors, or environmental. By choosing mate Genetic factors and environmental factors case will be closed, because religious education will happen in in the family and social environment; but here family environment plays a more important role. A child spends most of his educational proses in family. When couples are physically and mentally healthy, and spiritually righteous, a big portion of child education is completed. (Hossainzade, 2001, p. 42).

Given that the impact of the mother in the child education, such as environment and heredity is a lot, Islam emphasized on it so much.

\section{Attention to the basic needs In the religious education:}

\subsection{Love toward child:}

The first caretaker of the child is family. It is required for family to pay special attention to the child and they should know proper answering to the child forms the basis for his religious education. Fulfilling this need lead to mental relaxation, peace of mind, confidence, confidence in parents and even physical health and suppressing this need will lead to the collapse of psychological comfort, mistrust to yourself and others, feelings of helplessness and humiliation, physical and mental illnesses and social deviance. (Hossainzade, 2001, p 78).

Practices and traditions of leaders and infallible show the special attention of Islam's education school to this issue. Holy prophet of Islam loved his own children and his followers' children and even non-Muslim children and always told people to love children. (Majlesi, 1984, vol. 43, page5). He also said: "Love your children and give them mercy?." (Nouri altabarsi, 1987 AH, p. 231). Also said: "loving Look of father for his child is worship8." (Nouri altabarsi, 1987 AH,vol. 15, p. 170).

Therefore according to practices and traditions of leaders and infallible we understand that loving children and kids was one of their key aspects and this love was not limited to their children.

\subsection{Security:}

Safety for children and subordinates is important from several directions:

1. Regardless of religious education that are applied, basically, people need assurance to be able to establish a good relationship with others and subordinates; when they are sure that they have this trust they can say whatever they want and do what they want to do in peace and calm.

2. Children or adolescents that feel security and safety, can easily express their beliefs and thoughts so if they have any problem in their thoughts or beliefs parents will help them to correct them.

3. This feeling in children and adolescents allows them to express innovation, creativity.

4. Fear and insecurity led to repression and forced rejection in human thought and imagination, it may become a psychological complexes and cause many problems to humans (Hossainzade, 2001, p 95).

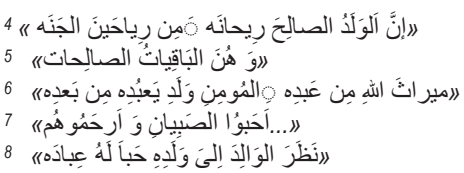




\subsection{Tolerance in religious education:}

God in the Quran says tolerance of the Prophet of God is caused by blessings upon the Prophet (PBUH) and a community of the Prophet (s) and says: "Because of God's mercy on them (Muslims) they were soft and if there was a coarse tempered and hardhearted between them, they would disappear"."(Ale Emran/159).

Narratives focused on tolerance a lot: "tolerance won't be placed on anything, it will make it beautiful 10" (Mohammadi rey shahri, 1983, vol.4, narrative 7355, p 156). Imam Ali called tolerance as "The key to salvation and attribute of wise men"(Mohammadi rey shahri, 1983, narrative 7361, p 157). Tolerance in our culture also has a long history, so that Hafez called it key to "Comfort of both worlds":

The comfort of two worlds is interpret of this word be generous with your friends and tolerate your enemies. (Hafez 1995, p 99).

Saadi also knows tolerance as a way to gain people's hearts 170).

With the grace of speech and tolerance and acceptance of people you will gain heart of people (Saadi, 1995, p

Also know tolerance as promoter of dignity:

With tolerance a person will achieve better things (Saadi 1995, p 129).

\subsubsection{The meaning and definition of tolerance:}

The word tolerance serves in the four meanings:

1- Doing a good job against doing it bad

2- Meek against irritability and violence

3- Moderation In the work

4- Hard work and accuracy in work (Altarihi, $1987 \mathrm{AH}$, vol.2).

Tolerance according to its literal meaning refers to the leniency in dealing with others. The leniency and softness sometimes is to avoid the evil of others and sometimes benefit from them. Generosity is used for pros and friends, while tolerance, especially precautions to tolerance is more used for opponents and enemies. It has been narrated: "do not impose anything on our Shia and deal with them gently11." (Kalini, $2012 \mathrm{AH}$, vol 8, narrative 522, p 334).

Another narrative says: "speaks tolerantly with opponents ${ }^{12 " ~(M o h a m m a d ~ r e y s h a h r i, ~ 1983, ~ v o l .3, ~ n a r r a t i o n ~ 5495, ~} p$ 239). In these two narratives the word Generosity is used for Shia and Tolerance for opponents. The meaning of these two words in Arabic and Farsi is education that is transferred from teacher to student, an education that the desired educational goals are discussed in it.

\subsubsection{Generosity and tolerance with others:}

Infallible Imams, when they wanted to explain something to people they talked according to understand the audience. The Prophet (PBUH) has been quoted that: "We have been ordered to talk to with people as much as their wisdom and understanding13." (Tabatabayi, 1997, narrative 1, page 57). Imam Sadeq has been quoted that: "The Messenger of Allah (pbuh) never spoke with people as much as his intellect and conscienc ${ }^{14}$ e." (Tabatabayi, 1997, narrative 1, page 57).

The reason that Infallible Imams spoke commensurate with the level of peoples understanding is two reasons:

First, the goal of teachers is to transfer their goal to the people and make successful changes; this will be achieved when students understand the meaning of their words, and this makes teachers to talk in same level of student's understanding.

Second, if this proportion is not respected, trainer not only reaches its goal, but also it is possible that misunderstandings happen, therefore the changes that the trainers don't want may happen. Thus, the Infallible Imams had put some content available only to certain people.

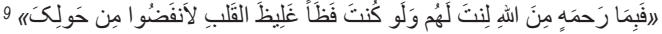

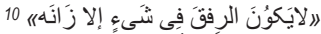

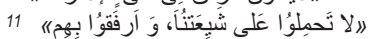

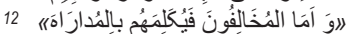

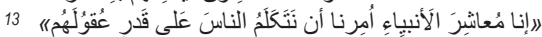

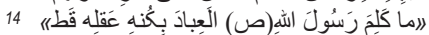




\subsubsection{Generosity and tolerance in religious education of children:}

Infallible Imams special attention to the effects of age difference in people, for them there was a difference between religious education of children and adults and expected certain thing from each of them; for example they did not expect the thing for young person, they expected from an old Shia. In the tradition of Imam Sajjad (AS) has been said: "Imam ordered children, to do their evening and night prayers together and afternoon and morning prayers together, and people asked him why they shouldn't do each prayed at their own time, he said it's better for them to sleep than pray'5. " (Nouri altabarsi, $1987 \mathrm{AH}$, vol 3, narration 1, p 19). These cases are examples of Generosity and Tolerance in religious education of children. He followed these steps in every situation. The range of tolerance in the Infallible Imams tradition of training is dependent on four criteria: ignorance or knowledge of person, Physical strength, obligatory or non-obligatory amount of faith and the action of person.

\subsubsection{Educational effects of tolerance and generosity:}

Tolerance and generosity have two educational effects:

First, the tolerance and generosity of trainers with their students makes them to have some kind of bound, to their trainer's Character, behavior and opinions. Imam Sadeq explains the generosity with people and specially the tolerance with opposites as this: to interest them in religion and also said: "But tolerate with opposites, to make them interested in religion ${ }^{16 . " ~(M o h a m m a d ~ r e y s h a h r i, ~ 1983, ~ v o l ~ 3, ~ n a r r a t i v e ~ 5495, ~ p ~ 239) . ~}$

Second, the tolerance and generosity of trainers with their students makes them to understand teachings and religious concepts better and gradually reach the higher level of faith and perfection without getting tired of them. In the recommendation of the Prophet (PBUH) to Ali (as) it had been said that: "don't make prayer for god hard for yourself; because overdoing will destroy your mount and u won't reach your destination"17"(Kalini, $2012 \mathrm{AH}$, vol 2, Narrative 6, $p$ 71).

This narration shows that, failure to comply tolerance and generosity in education, causes that the person get tired of religion and therefore hate it, so they will stop from passing the road to perfection. Therefore tolerance and generosity have two educational effects:

First: draws audience to learning;

Second: Causes the audience to understand the religious teachings.

\section{Educating children}

\subsection{Importance of educating children:}

Education and educating in Islam is so important that god has sworn on pen in Qur'an: "swear to the pen and what it writes ${ }^{18 . " ~(A L g h a l a m / 1) ~ I n ~ a n o t h e r ~ v e r s e ~ p r o v e s ~ t h e ~ s u p e r i o r i t y ~ o f ~ s c i e n c e ~ a n d ~ t h e ~ w o r l d ~ t o ~ t h e ~ h u m a n ~ c o n s c i e n c e ~ a n d ~}$ asks: "are people who know and people who don't know equal?". (ALzamar/9).

The holy prophet of Islam emphasized on knowledge and learning and at the start of his prophecy and encouraged people to do it. Therefore the importance of wisdom and knowledge was clear in Islam, but the thing that we focus here is the importance of teaching and educating in children; an era that Imam Ali said: "the child brain is like a flat land and its ready to be planted, and everything that we plant in there it will grow ${ }^{19 "}$ (Abde bita, vol 1, p 40) (Dashti, 2005, letter 31, p 368). The effect of educating in young ages was like this, (According to Imam Ali): "the effect of educating in young ages is like carving something on stone20" (Majlesi, 1982, vol 1, p 224). The shape that was carved on stone will never disappear and the education in early ages will be never forgotten. The holy prophet of Islam in addition to many orders that he gave to Muslims about educating children, he tried a lot to do this job for his own and his relative's children. When the great prophet of Islam became a prophet there were few people who could read and right but short after his prophecy

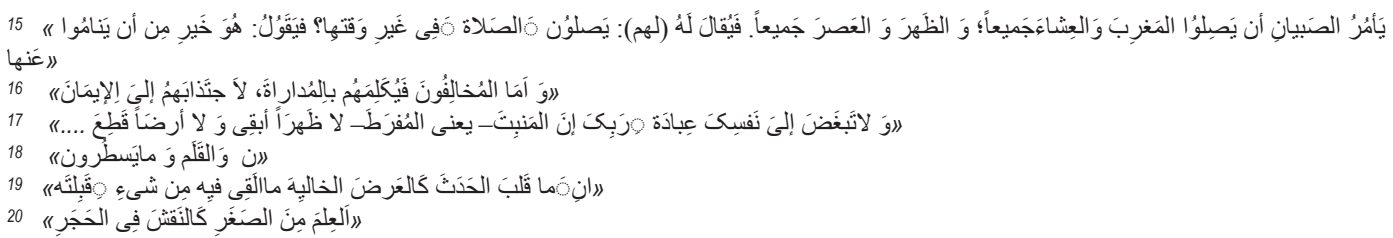


many people were encouraged to read and write and many did learn how to do it. Imam Ali did his best to educate children. In his will to Imam Hasan he said: "I educated you before your heart became hard and your mind became busy". ${ }^{21}$ (Abde, bita, vol 3, p 40). It is clear, discipline and training, will not be effective without education. Imam Ali also said:" First I thought you the Book of Allah, the Qur'an and its interpretation and religion beliefs22". (Abde, bita, vol3, p 40). Therefore in Infallibles Sire childhood and adolescence is a period of training and educating children in this period is parent's duty. Prophet Muhammad (PBUH) said: "Children have to play the $1^{\text {st }}$ seven years of life and spend $2^{\text {nd }}$ seven years to learn literacy and $3^{\text {rd }}$ seven years to train and learn the commandments23" (Hor Ameli, 1988, vol 15, p 194). Imam Ali said: "Children should be free up to seven years and $2^{\text {nd }}$ seven years they should be educated and, in $3^{\text {rd }}$ seven years [III] should be employed."24 (Nouri altabarasi, 1987, p 234). Education in this period is so important that Imam Ali said: "order your children to learn knowledge25" (Motaghi, 1988, vol 16, p 584). So it is parent's duty to educate their children in $2^{\text {nd }}$ period, and the educating in next period is up the child himself.

\subsection{Child education content:}

\subsubsection{Teaching to read and write:}

Basically, the introduction of any type of education to children is teaching reading and writing. Using prisoners to educate children, and announcing Abdolah Ebne Ass in Madineh mosque to teach writing and reading, shows the attention of holy prophet to education. In addition to teaching and writing, brief teaching of required Science for individuals in society was $\mathrm{n}$ program of schools of that time. Attention of Imam Ali to education of children was not only on reading and writing, he said: "As a child, learn science, so when you get older you can have sovereignty"26 (Abde, bita vol 20, p 267). And also said: "He who does not learn science when he is a child can't overtake the others when he is an adult." ${ }^{27}$ (Khansari, 1994, vol5, nom 8937, page 401).

It is clear that, the knowledge which leads to sovereignty is not only reading books but it is also things that are related and useful in the society that they live in, Part of it can be considered equivalent to primary education.

\subsubsection{Teaching Quran:}

Another part of the education of innocents (PBUH). is teaching the Qur'an that is very important. Imam Ali to his son Imam Hasan: "I started your education with teaching you book of god28". (Abde, bita, vol 3, p41). Imam Hussein sent his child to school to learn Quran. (Nouri altabarasi, 1987, vol 4, nom 4613, page 247). Therefore the importance of teaching Quran is so much that innocents count it as one of children's rights.

\subsubsection{Teaching religious customs}

Teaching customs in their tradition was not only in the classroom or school, but rather when the child reached the age, that needs to know the customs, they would teach them these customs, teaching customs was not only for children but rather for adults, infallibles taught and remind them the customs. In their sire they paid much attention to teaching prayers to children, and they also said the age for children to start their prayers is seven. Imam Sadeq told one of his followers to order their kids to pray from the age of five. (Horalmeli, 1988. Vol 4, narrative 5, p 19).

Infallibles use to follow these steps to teach prayers to children:

1- Practical Approach: it means they prayed in front of others so they can learn how to do it, and clear their mistakes in the right time.

2- Parents made them to do their prayers.

3- They teach them discretions of prayers, but they stopped them from overdoing discretions.

4- They made congregational prayers in moderate level so the children could attend it.

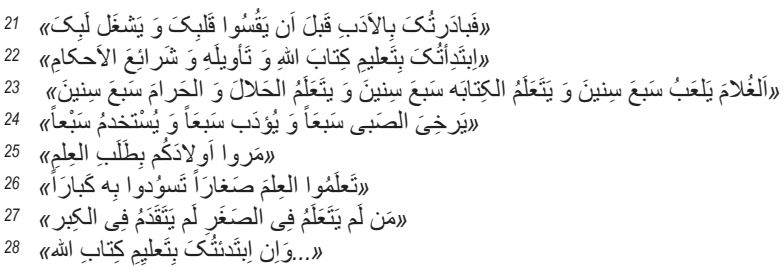


5- They started teaching prayers before the age of seven.

6- In doing prayers they are not strict, so the children get used to it slowly. (Davudi, 2010, p 119-127).

In Quran God asks a believer to remember him a lot: "O you who believe! Remember Allah much and say the rosary in the morning and evening."29 (AL ahzab/41-42). Imams also asked their followers to remember Allah a lot. Imam Reza (AS) told his companions: "Weapons of the prophets upon you." The question is; what is the weapon of prophets? He said: "Praying" (Kalini, 1992, vol 2, narrative 5, p 468).

Because of importance of prayers and remembrance of god, Imam taught them to people like this:

They recommend others to pray.

They encouraged people who pray and chant.

They taught some prayers and chants to people.

They made children accustomed to chanting and prayer. (Davudi, 2010, p 128-132).

\subsubsection{Teaching Practices and traditions:}

Another part of teaching is teaching Practices, traditions and Interpretation of the Qur'an. Imam Ali to Imam Hasan: "I started your education with teaching Quran and Interpretation of it and teaching Religion provisions and halal and haram"30. (Abde, bita, vol 3, p 41).

Teaching Religion provisions and traditions of Imams in moral and religious grounds, is a way to arm their children against diversion. Imam Sajad counts this kind of teaching as children's right and he said: "You, the parents you are responsible for your children's obedience toward God and their education, so do your job like you know if you do a good job you will be rewarded and I you do a bad job you will be punished" ${ }^{31}$ (Nouri altabarsi, 1987, p 445).

The point here is that these teaching should happen before person's brain becomes full of life problems or before wrong thoughts go in there, because Youngers brain is freer to accept these. If young people s mind be filled with good and right orders and opinions, bad orders won't have any place there and the reverse is possible.

\subsubsection{Teaching philosophy:}

The word Hekmat is a hardware that is placed in horse's mouth, so it can control the horse, because this hardware is made of hard metal and it's indestructible, so we call the knowledge that can't be rejected and its certain fact Hekmat or philosophy. Hekmat means understanding the verse. (Altarihi, 1987, vol 2). Advices and wisdoms that fathers gain from experiences or get it from pioneers of religion may be ignored by their children when they are kids but it is very important in the future of children, because soon or later the young ages will pass and children need advices and wisdoms. There were people who reached greatness with just following some of their parent's advices.

Infallibles use to teach their children these stuff and they ordered their followers to do the same. It is need that parents teach their experiences to their children and children should be owner of their parent's experience. Imam Ali said: "My child it is right that I haven't lived with elders but I have analyzed them so much that I feel like I am one of them, I understood bad thing and good things, I avoided doing bad thing and as you see I am beside you like a kind father" (Abde, bita,vol 3, letter 31,p 41) (Dashti, 2005, letter 31, page 368).

\subsubsection{Teaching customs of community}

Customs are set of rules of conduct that show; how should members of society act in different situations. In fact, customs pattern of human behavior in different social situations.

In the tradition training of Infallibles special attention was paid to social customs. They corrected contrary customs to Islam and if correction was no possible, they would be replaced with Islamic customs. Basically, the culture of a society is closely linked to the personality of people. This relationship is so intense that some sociologists say: As a natural condition and behavior of people is mirrored facade culture characters also occur as a result of being cultured and the concept of character, at least partially, is the representative uptake of substances in the environment (culture). (Ruh al amini, 1989, p 59). The effectiveness of customs training has special characteristic, it affects people indirectly and without

\footnotetext{
292

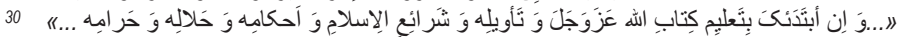

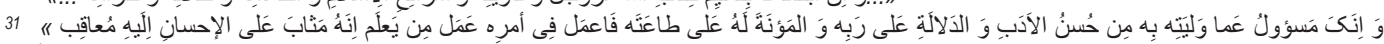
عَلى الإساءَة وإِلَّها
} 
compulsion and sensible coercion. When a person lives in a society, he knows he should obey social customs and beliefs of that place, although no one is forcing him. In the other words, the culture of each society itself and without any external factor will be imposed on people who live in the territory. Thus social customs are powerful tool to educate people, and inject beliefs and values in them. Maybe the reason for attention of Imams on this subject is this; spreading rules and customs that are against Islamic costumes causes undermining the opinions, beliefs and values of Islam and if the opposite happened beliefs and values of Islam will be celebrated.

One way of influencing someone's personality and their development is teaching and spreading Islamic customs. These ways are more effective that military ways. This is one of reasons that mass media, cultural literature, art and other cultural tools are important, therefore custodians of Islamic education should be more active to educate and promote Islamic customs. Accordingly, it can be said:

1- Customs are common rules among a group of people which determines how we should behave in any given situation.

2- The sire of Prophet (PBUH) and other Imams (as) in dealing with customs was like this, that they correct customs against Islam and if correction was not possible they would be replaced.

3- Customs inconsistent and contrary to the Islamic culture has adverse effect on people's character. (Davudi

\section{Parents and religious education of children}

Imams Sire shows the importance of father in educating the children. (Tabatabayi, 1996, p 157, narrative 158). Imam Sajjad (AS) Treatise on rights: "Good discipline of the child, his guidance to the Lord (swt), and help him to obey God" are the rights of children. This narration shows the responsibility of father. (Majlesi, 1982, vol 71, p 6).

Of course Imams Sire is rooted from Quran, in Quran god ordered parents to pay attention to their children's education. In $6^{\text {th }}$ verse of Tahrim Sura has been said: "O you who believe keep your family away from the fire that its fuels are men and stones $32 "$.

The Prophet (pbuh) explicitly considers a woman the protector of family her husband and her children. One of the children materials is efforts of the religious education. Also Imam Ali said: "Teach yourself and your family good manners and good deeds"33 (Makarem Shirazi, 1992, vol 24, p 294).

\subsection{Mandatory or preferences of parental responsibility in religious education:}

Jurists are against forcing praying and fasting to children. This means it is recommended that parents force their children to pray or fast; but they are forbidden to do bad stuff. For example, forbidding absence to children and stuff like this are mandatory for children. Parental responsibility in the field of religious education is not mandatory but rather is recommended and preference. Therefore if parents don't educate their children, they haven't done any sin; although according to law and custom they have left a good habit, anyway this responsibility is preference but it is good not to leave them. (Tabatabayi, 1997. Vol 7, p 102). We can say that the recommendation about the obligation and responsibility is emphatically recommendation.

\subsection{The duty of parents to perform religious responsibility:}

Teaching matters such as prayer, Hajj, recitation of the Quran, care and precision movement of children with others is one of Religious education responsibilities of parents, in addition to prayers other thing like morality and behavior with others, as well as customs eating, walking, sleeping, etc is in area of parents responsibility; According to the Treatise on rights of Imam Sajjad (AS) can be stated that leading children to God is considered as right of children, Beliefs education is one of Religious education responsibilities of parents. (Davudi, 2010, p 273-276).

The responsibility of parent is not to train an obedience child, but it is to guide them, show them right and wrong, the ability of being trained is now same in all people, so the responsibility of parents is to make them aware of things and teach them religious customs and make them obey god and his orders.

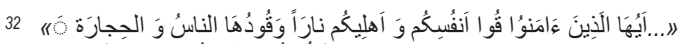

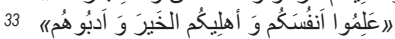




\subsection{Necessity and efficiency of parents educational responsibilities}

Parental responsibility in religious education does not negate the responsibilities of educational institutions. They complete each other. It is parent's responsibility to send their children to these institutes so it's one of parent educational responsibilities to conduct a program to use educational institutions in the community to educate their children.

Another dimension of educational responsibilities of parents is direct entry to the religious education of their children. In this case we can mention matters like: Training children for prayer and fasting, Care and supervision to practice religion, monitoring their trips with friends, compliance with Islamic customs in socializing, movement and general religious education in prayer and worship, morals and beliefs. The only responsibility of parents in this case is making them aware of divine laws and stoping them from perusing forbidden stuff.

Parents play an important role in the religious education of their children for various reasons:

First, they have a greater incentive than others do.

Second, children in the best period of training, they spend most of their time in the family.

Third, children up to the age of twenty economically and psychologically are dependent parents. (Davudi, 2010, $p$ 276- 279) And this dependence will be an important factor in the effectiveness of them.

Many researches show that, Parental influence on children's attitudes, especially in early ages of life, is much deeper and more stable than other learning attitude. (Sharifi, 2010, p 179-181) Social psychologists focused on family education influence on human character. Some of them believe, Type of raising children in a society, is key to understanding culture and education of the community; Family education is the foundation of any social education. (hashemi, 1996.vol 1, p 115). Others say: The main character of the original organization or individual character of each community and culture, rooted in primary education, If same as the number of people we have different personalities; They all share some characteristics that is called original character, As a result, the main character of any society is the product style and the family education in childhood. (Hashemi, 132, p 116). We can say that educational policy is not only necessary, But rather compared to the alternatives has a higher efficiency.

\section{Conclusion}

The most important function of religion is give meaning to life and no other phenomenon can be sufficient to assume this role, Thus, the necessity of existence of God and religion is inevitable and it belongs to all times, In other words, necessity of faith lies in need to respond to the fundamental questions of man. These days this fact is more important because of rise of technology and issues that people have. Yet religious education is essential, especially in children.

The teachings of the Holy Quran, the Sire of infallible and interpretations of religious scholars all led us to this issue. He stated the principles and branches that some of them were briefly mentioned in this study. Background of religious education for children and referring to some examples of the realization of this important, was included in this study. Loving children, security and tolerance for children, as well as teaching them religion customs like: Teaching the Quran, rules, traditions, Hekmat and other things like education, social customs to the children are responsibilities of parents and right of the children.

\section{References}

Quran, 1993, Translated by Elahe Ghomshe e, Tehran: Khorshid.

Hafez, 1995, Divan hafez, Qazvini correction, fifth edi, Tehran, Asatir Hor Ameli, 1988, Vasael alshia. Vol 20, 4 and 15, Sixth edi, Teharan,Islamie

Hossainzade, 2001, parenting educational Sire of the Prophet (PBUH) and Ahl al-Bayt (AS).vol 1.first edi, Qom: Institute of Science

Khansari, M., 1994 n. sharh ghararalhakam va daralakam. Fourth Edition, Tehran: Tehran University, vol 5 and 7 No. 8937

Davudi, M., 2010 n. Religious education and educational Sire the Prophet (PBUH) and Ahl al-Bayt (AS). Sixth Edition, Volume 2, published by Institute of Science

Dashti, M., 2005 n. Translation Nahjolbalaghe. Sixth edition, Qom, Hadi Publishing

Dilshod Tehrani, M 1997, p. Siri Islamic upbringing. Tehran: Publication and Research Institute zekr

Razi, 1999, Alghyb Mafatih interpretation. Publication Beirut, Darahya' Altras Arabi, Vol 32

Rouholamini, 1989, Culturology field. Second Edition, Tehran: Attar

Saadi, 1995, Bustan. Gholam Hossein Yousefi correction. Fourth Edition, Tehran: KHARAZMI

Saadi, 1995, Golestan. Gholam Hossein Yousefi correction, Fourth Edition, Tehran: KHARAZMI

Shariatmadari, 2008, Educational Psychology. Tehran: Amir Kabir, vol III

Sharifi, 2010, article how to shape the attitudes of students, Proceedings of the Symposium on the status of education in primary school 
education, Tehran: Education

Tabatabai, 1996, Traditions of the Prophet (PBUH). Translation and legal research. Sixth Edition, Tehran, bookstores Islamiyah, narration 158

Tabatabai, 1997, the most trustworthy handhold. Najaf: Press Zahra vol. 7, narration 1

Altarihi, 1987, albahrain Assembly. Edited and corrected Mahmoud Adel, Volume 2, Second Edition, Tehran, Islamic Culture Publications Office

18. Abdo, bi ta. Description of Nahjolbalaghe, 3, Beirut, Lebanon, with Almarefa for mailing Va alnashr

El Kleene, 2012, al-Kafi Alfrv me. 8 vol, correction and suspension A. Ghaffar, Tehran books of al-vol 8, narration 522 and vol2 narration 6

El Kleene, 1992, Al-Kafi principles. The second edition, Tehran, Beirut: al Daralktb, vol. 2 and 6, narration 5

Muttaqi, 1988, Al-Murshid to Knzalmal Fi and Alafal Alaqval traditions. Third Edition, Beirut: Institute of Al-Risala, vol 16

Majlesi, 1984, Alqvi Fi Marathi news stories Rasool (PBUH). The first edition, Vol. 43, Tehran: Daralktb Islamiyah

Majlesi, 1982, Bahar al anvar, Beirut: Institute Publications enforceable, vol. 7

Mohammadi Reyshahri, 1983, the Wisdom. 10 volumes, vol. 3 and 4, Qom, Islamic Propagation Office

Motahari, 1988, Siri Prophet. Tehran: Sadra

Makarem Shirazi, women and others, 1992, p. Sample interpretation. Second Edition, Tehran, books of al-vol24

Nuri altabarsi, 1987, Mustadrak Alvsayl and Mstnbt catechism. Beirut: Institute for Research and al-Bayt (AS) house Alsanyh, vol $15,11,4,3$

Hashemi, 1993, Create understanding and religious trends in children (Proceedings of the Second Symposium on the status of education in education), deputy of the Ministry of Education, Tehran: Education

Hashemi, 1996, Education and human character. 3 vol, vol 1, Qom, Islamic Propagation Office 